of art; and the catalogue (though not wholly innocent of the same tendency) contains an essay by W. G. Archer and Robert Melville which is a valuable stimulant to thought about primitive and modern art and their interrelations, and in which both artists and ethnologists may find not a few provocative sentences. We may hope that the collaboration between art and science will be pushed much further.

$6 \mid \dot{t}$

WILLIAM FAGG

\section{SECULAR CHANGES IN THE EARTH'S MAGNETIC FIELD}

R. E. CHBMARD has described (Mon. Not. Roy. As. Soc., Geophys. Supp., 5, No. 7, July 194. the rapid changes in the earth's magnetic field in South Africa, from which certain tentative (01) lusions are drawn. From data in tables 25, 29 and 33 in "Descriptions of the Earth's Main Magnetic Field and its Secular Changes", by E. H. Vestine and others (Carnegie Institution, Washington, 1947), a diagram is constructed showing the annual changes in the horizontal and vertical fields in South Africa at 1922.5 ; this date has been chosen because it is believed that the secular variations are better known then than at any other time.

From detailed calculations it seems possible that motions in the liquid core of the earth can partly explain the rapidity of change, though, as shown in the calculations, it is difficult to obtain a sufficient field by these means. Some of this difficulty, it is hoped, may be removed by a more thorough analysis of the secular change. The movement of the material of the earth's core through the general magnetic field of the earth could induce electric currents which produce the secular changes in the magnetic field, and the world-wide part of the change may be due to motions some thousands of kilometres in diameter. From 1843 to 1900 the change at Cape Town was comparatively small $(0.02$ gauss in all $)$ and may not have been due to a local eddy.

No explanation is given regarding the causes of the motions in the liquid core, but it is suggested that radioactive generation of heat there might produce thermal convective currents. A similar effect would result from asymmetry in the earth's cooling, and another possibility is that the slipping of the outer part of the earth over the core, while the earth's rotation slows down by tidal friction, may have had some effect.

A full investigation of the theory proposed would be a tedious matter, and it is not suggested that it is complete at present, but it is hoped that it will "stimulate modifications that will agree more exactly with the very complicated facts".

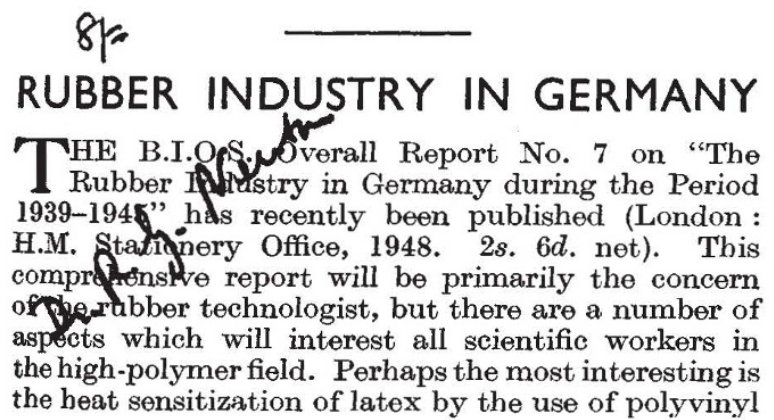

ether ('Igevin M50'), because the process depends upon the curious fact that this material is soluble in latex or water at room temperatures, but becomes insoluble at $35^{\circ} \mathrm{C}$., and causes the rubber to coagulate as it separates out. 'Igevin M50' is used in 3-7 per cent concentration referred to the rubber content, and the mixed solution is indefinitely stable at $25^{\circ} \mathrm{C}$., thus contrasting markedly with other heat-sensitizing materials.

The German synthetic rubber industry started long before the American industry, and it has been of interest to note that, in each case, the bulk of the synthetic rubber produced was of the butadienestyrene type, with butadiene-acrylonitrile polymers running second. What has not been generally realized, however, is that the Germans also had a large number of varieties, not only of the butadiene-styrene type, but also of other types, and these are described on pages 22-30 of the report. Two promising polymers of which little has previously been heard are 'Buna $\mathrm{K}$ ', a copolymer of butadiene and methyl vinyl ketone, and 'Buna M', where butadiene was polymerized with methyl methacrylate.

Another synthetic rubber which seems to show remarkable promise is 'Vulkollan N'. This is an ester-type rubber, prepared from polyethylene adipate and naphthalene di-isocyanate, which it is claimed will render all other polyester rubbers obsolete, being non-hardening, of high tear-resistance, and having lower hysteresis. Its resistance to abrasion is said to be ten times that of natural rubber, the tear-resistance is 53 per cent higher, and the solvent resistance is equal to that of 'Perbunan'; it will be interesting to see whether the manufacture of this rubber can be made a commercial proposition.

In the field of testing, the Germans were actively aware of the prime importance of laboratory tests for the 'processability' of their polymers, and they developed many tests which will be of interest to those technologists who had to struggle with the intractable rubbers which were the early product of the American industry. Other subjects of particular interest to technologists are the new non-black reinforcing fillers 'Tonerdegel' and 'White Carbon', the account of abrasion machines, and the discussion of thermal plasticization. R. G. NEwToN

\section{1= \\ FORTHCOMING EVENTS}

(Meetings marked with an asterisk * are open to the public)

Monday, January 24

UNIVERSTTY LONDON (in the Physiology Theatre, University College, 00 Street, London, W.C.1), at 4.45 p.m.-Dr. P. Johnson "The Utrace trifuge and Electrophoresis Apparatus in Protein Rerarch .* UFurther Lectures on January 31, February 7 and Fehpetry 14.) ROYAL GEOGRAPHTCAL SOCIETY (at Kensington Gore, London,
s.W.7), at 5 p.m.-Prof. C. G. Rossby : "Air Mass Meteorology-its S.W.7), at 5 p.m.- Prof. C,
Geographical Implications;.

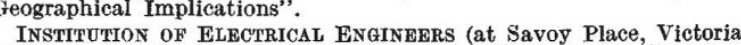
Embankment, London, W.C.2), at 5.30 p.m.-Discussion on "Generation of Electricity by Gas Turbine Plant".

Manchester Literary and Philosophical Society (in the Reynolds Hall, College of Technology, Manchester), at 5.30 p.m.Symposium on "Juvenile Delinqueney"."

TEXTILE INSTITUTe, YoRKSHIRE SECTion (at Alexandra Café, King TEXTILE INSTITUTE, YORKSHIRE SECTION (at Alexandra Café, King
Edward Street, Halifax), at 7.30 p.m.-Mr. F. L. Goodall : "The Edward Street, Halifax), at,
Battle against Textile Pests".

Chemtcal Society, OXFord SEction (in the Physical Chemistry Laboratory, Oxford), at 8.15 p.m.-Prof. N. V. Sidgwick, F.R.S. "Some Remarks on the Periodic Table" (Alembic Club Lecture).

\section{Tuesday, January 25}

INSTITUTE OF FUEL (at the Institution of Mechanical Engineers Storey's Gate, St. James's Park, London, S.W.1), at 10 a.m. and 2 p.m.-Conference on "Combined Heat and Power Supplies"." 